\title{
PROSES BERPIKIR SISWA KELAS IX SEKOLAH MENENGAH PERTAMA YANG BERKEMAMPUAN MATEMATIKA TINGGI DALAM MEMECAHKAN MASALAH MATEMATIKA
}

\author{
Tri Atmojo K ${ }^{1)}$, Imam Sujadi ${ }^{2)}$, Muhtarom ${ }^{3)}$ \\ ${ }^{1,2)}$ Program Pascasarjana Pendidikan Matematika Universitas Sebelas Maret \\ Jl. Ir. Sutami No 36 A Kentingan Surakarta. \\ ${ }^{3)}$ Dosen Pendidikan Matematika IKIP PGRI Semarang \\ Jl. Lontar Nomor 1 (Sidodadi Timur) Semarang Indonesia
}

\begin{abstract}
ABSTRAK
This study aim to describe the students' thinking process of $9^{\text {th }}$ grade of Junior High School has a high mathematics capability in solving the mathematics problem based on Polya rule.

This study is qualitative descriptive research. The criteria of subject selection included the students' has a high mathematics capability and communication fluency both spoken and written. The data collection was done using written test and task-based interview techniques. Data analysis done based on written test data and task-based interview techniques data. And then it has been done the method triangulation to get valid subject data.

Finally, the result of description thinking process as follows: students with high mathematics capability, in understanding problem using assimilation thinking process, make a plan using assimilation and accommodation thinking process. Assimilation thinking process can be identified when the students can mention the prerequisite material, can directly relate the sides kite $(\mathrm{BF}=\mathrm{FG})$ and can directly develop problem solving plan. Meanwhile, accommodation thinking process can be seen when the students drew an auxiliary line from $\mathrm{E}$ to the right thereby intersecting with $\mathrm{CD}$ line (the intersection was labeled $\mathrm{H}$ point), so devided trapezoid AEDG become right triangle EHG and rectangle AEHD. In carrying out a plan and in looking back at the completed solution, the students used assimilation thinking process.
\end{abstract}

Keywords: thinking process, mathematics problem, and problem solving.

\section{PENDAHULUAN}

Setiap siswa tidak dapat menghindar dari kesulitan belajar matematika. Jika siswa menghindar dari kesulitan termasuk dalam belajar matematika hanya untuk tujuan pragmatis, mencari mudahnya saja, sama artinya menjerumuskan diri dalam kebodohan dan akan berhadapan dengan kesulitan lain yang lebih besar. Oleh karena itu, siswa perlu berusaha memotivasi diri untuk lebih menyenangi matematika. Siswa perlu menanamkan dalam benaknya bahwa matematika itu penting. Sesuai dengan tujuan pembelajaran matematika yaitu memecahkan masalah, maka setiap siswa pasti akan menjumpai masalah matematika dalam pembelajaran. Meskipun pemecahan masalah membutuhkan pemikiran tingkat tinggi, akan tetapi kemampuan pemecahan masalah sebenarnya dapat dilatihkan.

Dalam memecahkan masalah, siswa melakukan proses berpikir dalam benak sehingga siswa dapat sampai pada jawaban. Menurut Yulaelawati (2004) salah satu peran pendidik dalam pembelajaran matematika adalah membantu siswa mengungkapkan bagaimana proses yang berjalan dalam pikirannya ketika memecahkan masalah, misalnya dengan cara meminta siswa menceritakan langkah yang ada dalam 
pikirannya. Hal ini diperlukan untuk mengetahui kesalahan berpikir yang terjadi dan merapikan jaringan pengetahuan siswa. Selain itu, peran pendidik adalah menciptakan kondisi pembelajaran yang mampu membiasakan siswa untuk melakukan penyelidikan dan penemuan (Dewiyani, 2008).

Jika guru dapat mengetahui proses berpikir siswa, maka dapat diketahui jenis kesalahan yang dilakukan siswa. Kesalahan yang diperbuat siswa dapat dijadikan sumber informasi belajar dan pemahaman bagi siswa. Karena dengan mengungkapkan proses berpikir siswa tersebut akan dapat memberikan kontribusi pada pengembangan pembelajaran matematika. Jika siswa yang mempunyai kemampuan matematika tinggi banyak melakukan kesalahan proses berpikir dalam memecahkan masalah matematika, dimungkinkan untuk siswa yang mempunyai kemampuan matematika sedang dan rendah juga terjadi kesalahan yang serupa. Oleh karena itu perlu dilakukan penelitian mengetahui lebih jauh proses berpikir siswa kelas IX SMP yang mempunyai kemampuan matematika tinggi dalam memecahkan masalah matematika. Pertanyaan dalam penelitian dirumuskan sebagai berikut: bagaimana proses berpikir siswa kelas IX SMP yang mempunyai kemampuan matematika tinggi dalam memecahkan masalah matematika.

\section{LANDASAN TEORI}

Berpikir memerlukan dua komponen utama yaitu informasi yang masuk dan skema yang telah terbentuk dan tersimpan dalam pikiran setiap individu. Piaget dalam Shahnaz Qayumi (2001) menyatakan bahwa melalui kegiatan refleks, merasakan dan gerak motorik seorang siswa akan membentuk skema. Skema terbentuk karena pengalaman (Wina Sanjaya, 2009). Berkaitan dengan skema kognitif Piaget (dalam William Crain, 1992: 104) menyatakan struktur mental atau kognitif individu secara intelektual beradaptasi dan mengkoordinasikan lingkungan sekitarnya.

DeVries (2006) mengungkapakn bahwa children construct schemes of social reaction just as they construct schemes relating to the world of objects. Interest in others leads to voluntary (autonomous) social efforts. Skema itu akan beradaptasi dan berubah selama perkembangan mental anak. Skema juga merupakan suatu rangkaian proses dalam sistem kesadaran seseorang (Suparno, 2001). Piaget dalam Qayumi (2001) menyatakan bahwa melalui kegiatan refleks, merasakan dan gerak motorik seorang siswa akan membentuk skema. Skema terbentuk karena pengalaman (Sanjaya, 2009). Berkaitan dengan skema kognitif Piaget (dalam Crain, 1992: 104) menyatakan struktur mental atau kognitif individu secara intelektual beradaptasi dan mengkoordinasikan lingkungan sekitarnya dengan cara asimilasi atau akomodasi.

$$
\text { Asimilasi merupakan proses }
$$

pengintegrasian secara langsung stimulus baru ke dalam skema yang telah ada. Jerry Glover (2002) menjelaskan konsep assimilation to mean taking in information for which the learner already has structures in place, enabling him or her to recognize and attach 
meaning to the information being received. Sedangkan Melnick (1974) mengungkapkan assimilation is the incorporation of feature of the environment into already existing structures. Akomodasi adalah proses pengintegrasian stimulus baru melalui pengubahan skema lama atau pembentukan skema baru untuk menyesuaikan dengan stimulus yang diterima. Hal ini terjadi karena pengalaman baru itu sama sekali tidak cocok dengan skema yang telah ada (Suparno, 2001). Sedangkan Melnick (1974) mengungkapkan accomadition is the modification of existing structures according to the demands of the environment. Stimulus yang diterima mungkin saja tidak sesuai dengan skema lama, oleh karena itu skema lama yang harus disesuaikan atau diubah hingga sesuai dengan stimulus yang masuk.

Pemecahan masalah secara sederhana merupakan proses penerimaan masalah sebagai tantangan untuk memecahkannya. Pemecahan masalah melibatkan proses berpikir dan melibatkan penuh usaha. Problem solving is the cognitive process (Maarten W, 1994). Hal ini mengartikan bahwa tanpa proses berpikir dan tanpa usaha yang penuh, maka bukan dikatakan memecahkan masalah. Ide tentang langkah-langkah pemecahan masalah dirumuskan oleh beberapa ahli. Sukayasa (2010) menuliskan perbandingan langkahlangkah dalam pemecahan masalah menurut beberapa pendapat ahli yang disajikan dalam Tabel 1. Pada penelitian ini akan menggunakan langkah pemecahan masalah menurut Polya, dengan alasan: (1) langkah-langkah dalam proses pemecahan masalah yang dikemukan Polya cukup sederhana, (2) aktivitas pada setiap langkah yang dikemukan Polya jelas maknanya dan, (3) langkah pemecahan masalah menurut Polya secara implisit mencakup semua langkah pemecahan masalah yang dikemukakan oleh ahli yang lain yang disajikan pada Tabel 1.

Tabel 1 Perbandingan Langkah dalam Pemecahan Masalah

\begin{tabular}{|c|c|c|}
\hline \multicolumn{3}{|c|}{ Fase-Fase Pemecahan masalah } \\
\hline Polya (1973) & $\begin{array}{l}\text { John Dewey dalam } \\
\text { Swadener (1985) }\end{array}$ & Krulik \& Rudnick (1995) \\
\hline $\begin{array}{l}\text { 1. Memahami masalah } \\
\text { (understanding } \\
\text { problem) }\end{array}$ & 1. Pengenalan (recognition) & $\begin{array}{l}\text { 1. Membaca dan memikirkan } \\
\text { (read and think) }\end{array}$ \\
\hline \multirow[t]{2}{*}{$\begin{array}{l}\text { 2. Membuat rencana } \\
\text { penyelesaian (devising a } \\
\text { plan) }\end{array}$} & $\begin{array}{l}\text { 2. Pendefinisian } \\
\text { (definition) }\end{array}$ & $\begin{array}{l}\text { 2. Mengeksplorasi } \\
\text { merencanakan (explore and } \\
\text { plan) }\end{array}$ \\
\hline & 3. Perumusan (formulation) & $\begin{array}{l}\text { 3. Memilih suatu strategi } \\
\text { (select a strategy) }\end{array}$ \\
\hline $\begin{array}{l}\text { 3. Melaksanakan rencana } \\
\text { penyelesaian (carrying } \\
\text { out a plan) }\end{array}$ & 4. Mencobakan (test) & $\begin{array}{l}\text { 4. Menemukan suatu jawaban } \\
\text { (find an answer) }\end{array}$ \\
\hline $\begin{array}{l}\text { 4. mengecek kembali } \\
\text { hasilnya (looking back) }\end{array}$ & 5. Evaluasi (evaluation) & $\begin{array}{l}\text { 5. Meninjau kembali } \text { dan } \\
\text { mendiskusikan (reflect } \\
\text { extend) }\end{array}$ \\
\hline
\end{tabular}

\section{METODE PENELITIAN}


Penelitian ini merupakan penelitian deskriptif kualitatif. Keabsahan data yang digunakan pada penelitian ini adalah kredibilitas (validitas) dan dependabilitas (reliabilitas). Selanjutnya untuk memperoleh data penelitian yang dapat dipercaya (credibility), teknik yang digunakan adalah dengan triangulasi metode. Sedangkan untuk menjaga dependabilitas dilakukan dengan cara mendokumentasikan semua kegiatan yang berhubungan dengan penelitian ini dan menjelaskan secara runtut semua alur penelitian yang dilakukan.

Subjek penelitian ini adalah seorang siswa kelas IX SMP N 2 Grobogan yang berkemampuan matematika tinggi. Kriteria pemilihan subjek didasarkan pada kemampuan matematika siswa, sudah mendapatkan materi Teorema Pythagoras, kelancaran berkomunikasi baik secara lisan maupun tulisan. Pengumpulan data dilakukan dengan teknik tes tertulis dan wawancara berbasis tugas. Analisis data dilakukan berdasarkan data tes tertulis dan data wawancara berbasis tugas. Data yang telah terkumpul baik dari tes tertulis maupun dari hasil wawancara dianalisis dengan langkah- langkah sebagai berikut: 1) Reduksi data yakni melakukan proses pemilihan, pemusatan perhatian penyederhanaan, pengabstraksian dan transformasi data mentah di lapangan; 2) Pemaparan data yakni mengklasifikasi dan mengidentifikasi data sehingga terorganisir dan terkategori dengan baik; 3) Menarik kesimpulan berdasarkan hasil paparan data. Setelah data dipaparkan sedemikianrupa sehingga terkategori dengan baik, maka langkah selanjutnya menarik kesimpulan atau menginterprestasikan makna dari paparan data tersebut. Selanjutnya dilakukan triangulasi metode untuk mendapatkan data subjek penelitian yang valid.

\section{HASIL DAN PEMBAHASAN}

Subjek dalam penelitian ini adalah seorang siswa berkemampuan matematika tinggi (kode DW). Pengambilan data tertulis dilakukan pada tanggal 19 Desember 2011 dan pengambilan data wawancara dilakukan pada tanggal 2 Januari 2012. Berikut ini adalah analisis proses berpikir subjek DW dalam memecahkan masalah, meliputi proses berpikir subjek DW dalam memahami masalah, membuat rencana pemecahan masalah, melaksanakan rencana pemecahan masalah dan mengecek kembali berdasarkan hasil pekerjaan tertulis:

Tabel 2. Analisis proses berpikir subjek DW dalam memecahkan masalah

\begin{tabular}{|c|c|c|c|}
\hline Memahami Masalah & $\begin{array}{l}\text { Menyusun Rencana } \\
\text { Pemecahan }\end{array}$ & $\begin{array}{c}\text { Melaksanakan Rencana } \\
\text { Pemecahan }\end{array}$ & $\begin{array}{c}\text { Memeriksa Kembali } \\
\text { Hasil Pemecahan }\end{array}$ \\
\hline \begin{tabular}{l}
\multicolumn{3}{l}{ Subjek DW } \\
- dapat dengan mudah \\
dan benar \\
mengetahui apa yang \\
ditanyakan, apa yang \\
diketahui r pada
\end{tabular} & $\begin{array}{l}\text { Subjek DW } \\
\text { - dengan lancar dan } \\
\text { benar menuliskan } \\
\text { pengetahuan lain } \\
\text { yang dapat } \\
\text { digunakan untuk }\end{array}$ & $\begin{array}{lr}\text { Subjek DW } & \\
\text { - dapat menjawab } \\
\text { masalah dengan } \\
\text { benar berdasarkan } \\
\text { langkah-langkah } \\
\text { pemecahan masalah }\end{array}$ & $\begin{array}{lr}\text { Subjek DW } & \\
\text { - meyakini kebenaran } \\
\text { hasil r yang } \\
\text { didapatkan dengan } \\
\text { melihat kembali } \\
\text { langkah-langkah dan }\end{array}$ \\
\hline
\end{tabular}




\begin{tabular}{|c|c|c|c|}
\hline $\begin{array}{l}\text { Landiktghlahalisis Data Tert } \\
\text { - dapat menentukan } \\
\text { apakah hal yang } \\
\text { diketahui } r \text { sudah } \\
\text { cukup atau belum } \\
\text { cukup untuk } \\
\text { menjawab apa yang } \\
\text { ditanyakan yaitu } \\
\text { belum cukup karena } \\
\text { BF belum diketahui }\end{array}$ & 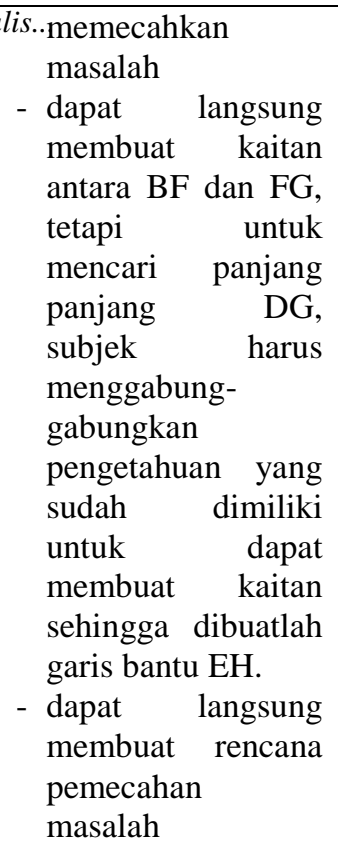 & $\begin{array}{l}\text { yang telah disusun } \\
\text { dan algoritma } \\
\text { perhitungan yang } \\
\text { dilakukan juga benar. }\end{array}$ & $\begin{array}{lr}\text { perhitungan yang } \\
\text { dilakukan } \\
\text { melaksanakan } \\
\text { pemecahan masalah. }\end{array}$ \\
\hline \multicolumn{4}{|c|}{$\begin{array}{l}\text { Kesimpulan: } \\
\text { Subjek DW dalam memahami masalah menggunakan proses berpikir asimilasi, dalam menyusun } \\
\text { rencana pemecahan masalah menggunakan proses berpikir asimilasi dan akomodasi. Proses berpikir } \\
\text { asimilasi dapat diidentifikasi ketika DW dapat menyebutkan materi prasyarat, dapat langsung } \\
\text { membuat kaitan antara panjang BF dan FG dan dapat langsung membuat rencana pemecahan } \\
\text { masalah. Sedangkan proses berpikir akomodasi terlihat ketika subjek DW membuat garis bantu dari } \\
\text { E yang ditarik ke kanan sehingga berpotongan dengan garis CD (perpotongannya diberi nama titik } \\
\text { H). Dalam melaksanakan rencana pemecahan masalah dan memeriksa kembali hasil pemecahan } \\
\text { subjek DW menggunakan proses berpikir asimilasi. }\end{array}$} \\
\hline
\end{tabular}

Dengan teknik analisis yang sama, maka didapatkan data analisis analisis proses berpikir subjek DW dalam memecahkan masalah, meliputi proses berpikir subjek DW dalam memahami masalah, membuat rencana pemecahan masalah, melaksanakan rencana pemecahan masalah dan mengecek kembali berdasarkan hasil wawancara. Selanjutnya dilakukan triangulasi metode untuk mendapatkan data subjek DW yang valid. Setelah diperoleh data subjek DW yang valid, selanjutnya data yang valid tersebut dibandingkan dengan indikator proses berpikir yang diajukan oleh peneliti, untuk dapat ditarik kesimpulan.

Tabel 3. Perbandingan hasil valiadasi data subyek DW dengan indicator proses berpikir

\begin{tabular}{|l|l|l|}
\hline \multicolumn{1}{|c|}{ Langkah } & \multicolumn{1}{|c|}{ Hasil Tertulis } & \multicolumn{1}{c|}{ Hasil Wawancara } \\
\hline Memahami & Subjek DW & Subjek DW \\
masalah & - dapat dengan mudah dan benar & - dapat dengan mudah dan benar \\
& mengetahui apa yang ditanyakan, apa & mengetahui apa yang ditanyakan, apa \\
& yang diketahui pada masalah diketahui pada masalah (DW-3, & yang dan-4, DW-6) \\
& - dapat menentukan apakah hal yang & DW-4, \\
& diketahui sudah cukup atau belum & - dapat menentukan apakah hal yang \\
& cukup untuk menjawab apa yang & diketahui sudah cukup atau belum \\
& ditanyakan yaitu belum cukup karena & cukup untuk menjawab apa yang \\
& BF belum diketahui. & ditanyakan yaitu belum cukup karena \\
\hline
\end{tabular}




\begin{tabular}{|c|c|c|}
\hline Lanjutan Triangul & isi Metode... & BF belum diketahui (DW-9). \\
\hline $\begin{array}{l}\text { Merencanakan } \\
\text { Pemecahan } \\
\text { Masalah }\end{array}$ & $\begin{array}{l}\text { Subjek DW } \\
\text { - dengan lancar dan benar menuliskan } \\
\text { pengetahuan lain yang dapat } \\
\text { digunakan untuk memecahkan } \\
\text { masalah } \\
\text { - dapat langsung membuat kaitan } \\
\text { antara BF dan FG, tetapi untuk } \\
\text { mencari panjang panjang DG, subjek } \\
\text { harus menggabung-gabungkan } \\
\text { pengetahuan yang sudah dimiliki } \\
\text { untuk dapat membuat kaitan } \\
\text { sehingga dibuatlah garis bantu EH } \\
\text { - dapat langsung membuat rencana } \\
\text { pemecahan masalah. }\end{array}$ & $\begin{array}{l}\text { Subjek DW } \\
\text { - dengan lancar dan benar } \\
\text { menyebutkan pengetahuan lain yang } \\
\text { dapat digunakan untuk memecahkan } \\
\text { masalah (DW-12) } \\
\text { - dapat langsung membuat kaitan } \\
\text { antara BF dan FG (DW-23), tetapi } \\
\text { untuk mencari panjang DG, subjek } \\
\text { harus menggabung-gabungkan } \\
\text { pengetahuan yang sudah dimiliki } \\
\text { untuk dapat membuat kaitan } \\
\text { sehingga dibuatlah garis bantu EH } \\
\text { (DW-21) - dapat langsung membuat rencana } \\
\text { pemecahan masalah (DW-29 s.d } \\
\text { DW-32). }\end{array}$ \\
\hline $\begin{array}{l}\text { Melaksanakan } \\
\text { Rencana } \\
\text { Pemecahan } \\
\text { Masalah }\end{array}$ & $\begin{array}{l}\text { Subjek DW } \\
\text { - dapat menjawab masalah dengan } \\
\text { benar berdasarkan langkah-langkah } \\
\text { pemecahan masalah yang telah } \\
\text { disusun dan algoritma perhitungan } \\
\text { yang dilakukan juga benar. }\end{array}$ & $\begin{array}{l}\text { Subjek DW } \\
\text { - dapat menjawab masalah dengan } \\
\text { benar berdasarkan langkah-langkah } \\
\text { pemecahan masalah yang telah } \\
\text { disusun dan algoritma perhitungan } \\
\text { yang dilakukan juga benar (DW-33 } \\
\text { s.d DW-54) }\end{array}$ \\
\hline $\begin{array}{l}\text { Mengecek } \\
\text { Kembali }\end{array}$ & $\begin{array}{l}\text { Subjek DW } \\
\text { - meyakini kebenaran hasil yang } \\
\text { didapatkan dengan melihat kembali } \\
\text { langkah-langkah dan perhitungan } \\
\text { yang dilakukan saat melaksanakan } \\
\text { pemecahan masalah. }\end{array}$ & $\begin{array}{l}\text { Subjek DW } \\
\text { - meyakini kebenaran hasil yang } \\
\text { didapatkan dengan melihat kembali } \\
\text { langkah-langkah dan perhitungan } \\
\text { yang dilakukan saat melaksanakan } \\
\text { pemecahan masalah (DW-57 s.d } \\
\text { DW-65). }\end{array}$ \\
\hline
\end{tabular}

Data subjek DW yang valid sebagai berikut:

1. Memahami masalah

a. dapat dengan mudah dan benar mengetahui apa yang ditanyakan, apa yang diketahui pada masalah

b. dapat menentukan apakah hal yang diketahui sudah cukup atau belum cukup untuk menjawab apa yang ditanyakan yaitu belum cukup karena BF belum diketahui.

2. Merencanakan pemecahan masalah

a. dengan lancar dan benar menuliskan pengetahuan lain yang dapat digunakan untuk memecahkan masalah

b. dapat langsung membuat kaitan antara BF dan FG, tetapi untuk mencari panjang panjang DG, subjek harus menggabung-gabungkan pengetahuan yang sudah dimiliki untuk dapat membuat kaitan sehingga dibuatlah garis bantu $\mathrm{EH}$

c. dapat langsung membuat rencana pemecahan masalah.

3. Melaksanakan rencana pemecahan masalah

dapat menjawab masalah dengan benar berdasarkan langkah-langkah pemecahan masalah yang telah disusun dan algoritma perhitungan yang dilakukan juga benar.

4. Mengecek kembali

meyakini kebenaran hasil yang didapatkan dengan melihat kembali langkah-langkah dan perhitungan yang dilakukan saat melaksanakan pemecahan masalah.

Kesimpulan:

Subjek DW dalam memahami masalah menggunakan proses berpikir asimilasi, dalam menyusun 
rencana pemecahan masalah menggunakan proses berpikir asimilasi dan akomodasi. Proses berpikir asimilasi dapat diidentifikasi ketika DW dapat menyebutkan materi prasyarat, dapat langsung membuat kaitan antara panjang BF dan FG dan dapat langsung membuat rencana pemecahan masalah. Sedangkan proses berpikir akomodasi terlihat ketika subjek DW membuat garis bantu dari E yang ditarik ke kanan sehingga berpotongan dengan garis CD (perpotongannya diberi nama titik $\mathrm{H}$ ), sehingga diketahui $\mathrm{EH}$ dan $\mathrm{DH}$ untuk mencari panjang DG. Dalam melaksanakan rencana pemecahan masalah dan memeriksa kembali hasil pemecahan subjek DW menggunakan proses berpikir asimilasi. 
Berdasarkan hasil triangulasi metode dapat disimpulkan bahwa subjek DW menggunakan proses berpikir asimilasi dalam memahami masalah. Pada tahap merencanakan pemecahan masalah subjek DW dengan lancar dan benar menyebutkan pengetahuan lain yang dapat digunakan untuk memecahkan masalah, dapat langsung membuat kaitan antara $\mathrm{BF}$ dan FG. Tetapi untuk mencari panjang DG pada trapesium EADG (pada trapesium ini $\mathrm{AE}, \mathrm{AD}$ sudah diketahui pada soal dan diminta mencari panjang DG, tetapi luas dan keliling trapesium EADG tidak diketahui) subjek harus memodifikasi struktur mental yang sudah dimilikinya sehingga dibuatlah garis EH. Garis EH membagi trapesium EADG menjadi segitiga siku-siku EHG dan persegi panjang AEHD. Setelah mampu membuat kaitan antar hal yang diketahui, akhirnya subjek dapat membuat rencana pemecahan masalah yang dapat dijadikan sebagai pedoman dalam pemecahan masalah. Dalam kaitan ini, maka subjek DW menggunakan proses berpikir asimilasi dan akomodasi. Proses berpikir akomodasi yang dilakukan oleh subjek dengan menggabungkan beberapa pengetahuan sehingga subjek membuat pola garis EH. Proses berpikir asimilasi pada tahap ini dilakukan oleh subjek ketika mampu menyebutkan pengetahuan lain dan dengan lancar mampu membuat rencana pemecahan masalah.

Dalam melaksanakan perencanaan pemecahan masalah, subjek DW menggunakan rencana pemecahan masalah yang telah disusun. Subjek berhasil menjawab masalah dengan benar tanpa mengalami hambatan yang berarti. Dalam kaitan ini, subjek menggunakan proses berpikir asimilasi. Dalam berpikir asimilasi subjek menggunakan sifat layang-layang dan Teorema Pythagoras. Sifat layang-layang digunakan untuk membuat perbandingan antara panjang $\mathrm{BF}$ dengan FG sehingga dapat dicari nilai FC, sedangkan Teorema Pythagoras digunakan untuk mencari panjang HG (bagian dari panjang DG) dan digunakan untuk mencari panjang EF. Selanjutnya pada tahap pengecekan kembali, subjek DW menggunakan proses berpikir asimilasi dengan cara melihat kembali pemecahan dan melihat kelemahan dari solusi yang didapatkan (seperti langkah-langkah yang tidak benar).

\section{SIMPULAN}

Berdasarkan hasil penelitian yang telah diuraikan, maka dapat ditarik kesimpulan bahwa siswa berkemampuan matematika tinggi dalam memahami masalah menggunakan proses berpikir asimilasi dengan menuliskan hal apa yang diketahui, apa yang ditanyakan dan jelas dalam menentukan kaitan apakah hal yang diketahui sudah cukup atau belum cukup untuk menjawab apa yang ditanyakan, dalam membuat rencana pemecahan masalah menggunakan proses berpikir asimilasi dan akomodasi. Proses berpikir asimilasi dapat diidentifikasi ketika menyebutkan pengetahuan lain yang dapat digunakan untuk memecahkan masalah, dapat langsung membuat kaitan antara $\mathrm{BF}$ dengan $\mathrm{FG}(\mathrm{BF}=\mathrm{FG})$ dan dapat langsung membuat rencana pemecahan masalah. Sedangkan proses berpikir akomodasi dapat diidentifikasi ketika membuat garis bantu $\mathrm{EH}$ 
untuk dapat mencari panjang DG pada trapesium EADG. Dalam melaksanakan rencana pemecahan masalah menggunakan proses berpikir asimilasi yaitu berhasil menjawab masalah dengan benar menggunakan rencana pemecahan masalah yang telah disusun dan dalam pengecekan kembali pemecahan menggunakan proses berpikir asimilasi dengan cara melihat kembali pemecahan dan melihat kelemahan dari solusi yang didapatkan (seperti langkah-langkah yang tidak benar).

\section{DAFTAR PUSTAKA}

Abbas N. 2000. Pengembangan Perangkat Pembelajaran Matematika Berorientasi Model Pembelajaran Berdasarkan Masalah (Problem Based-Instruction). Surabaya: PPs Universitas Negeri Surabaya.

Alex Sobur. 2003. Psikologi Umum dalam Lintasan Sejarah. Bandung: Pustaka Setia.

Alice Thomas, Glenda Thorne, Bob Small. 2001. Higher Order Thinking it's HOT. (Online).http://www.cdl.org/resource/ reading room/highorderthinking.html diakses tanggal 20 Agustus 2011.

Bambang Priyo Darminto. 2010. Peningkatan Kreativitas dan Pemecahan Masalah Bagi Calon Guru Matematika Melalui Pembelajaran Model Treffinger. Makalah disampaikan pada Seminar Nasional Matematika dan Pendidikan
Matematika di UNY pada tanggal 27 November 2010.

Begerson T. 2000. Teaching and Learning Mathematics: Using Research to Shift from the "Yesterday" Mind to the "Tomorrow" Mind. Washington: superintendent of Public Instruction. (Online). http://www.k12.wa.us. diakses tanggal 3 Agustus 2011.

Budiyono. 2003. Metodologi Penelitian Pendidikan. Surakarta: UNS Press.

Crawford and Brown. 2002. Focusing Upon Higher Order Thinking Skills: Webquest and The Learned-Centered Mathematical Learning Environment. US.Departement Of Education:ERIC.(Online).http://eric.e d.gov/ERICDocs/data/ericdocs2sql/co ntens_storage_01/0000019b/80/1a/14. pdf. Diakses tanggal 20 Agustus 2011.

Daniel Muijs dan David Reynold. 2008. Effective Teaching. Translated by Helly dan Sri Muyantini. 2008. Yogyakarta: Pustaka Belajar.

Depdiknas. 2008. Kumpulan Permendiknas tentang Standar Nasional Pendidikan (SNP) dan Panduan KTSP. Jakarta: Direktorat Pembinaan Sekolah Menengah Atas.

Dewiyani. 2008. Mengajarkan Pemecahan Masalah dengan Menggunakan 
Langkah Polya. Jurnal STIKOM, Volume 12 Nomor 2.

Erman Suherman, dkk. 2003. Strategi Pembelajaran Matematika

Kontemporer. Universitas Pendidikan Indonesia.

Henk Vos dan E. D. Graff. 2004. Developing Metacognition: a Basis For Active Learning. European Journal of Engineering Education. 29. 543-548.

Herman Hudoyo. 1988. Mengajar Belajar Matematika. Jakarta: Depdikbud.

Huitt. 1992. Problem Solving and Decision Making: Consideration of individual differences using the Myers-Briggs Type Indicator. Journal of Psychological Type.24.33-44. tersedia dalam:

http://chiron.valdosta.edu/whuitt/pape $\underline{\text { rs/prbsmbti.html. }}$ diakses $10 \quad$ Juli $\underline{2010 .}$.

Ismail. 2006. Materi Pokok Kapita Selekta Pembelajaran Matematika. Jakarta: Universitas Terbuka.

Jerry Glover. 2002. Adaptive Leadership: When Change is Not Enough. The Organization Development Journal. 20 (2). 15-31.

Lexy J Moleong. 2007. Metodologi Penelitian Kualitatif. Bandung: Remaja Rosdakarya Offset.
Lutfiyah. 2009. Proses Berpikir Siswa dalam Mengkonstruksi Pengetahuan Himpunan Dalam Aktivitas Think Pair Share. Tesis. Malang: PPs Universitas Negeri Malang.

Maarten W. van Someren, Yvonne F. Barnard, dan Jacobijn A.C. Sandberg. 1994. The Think Aloud Method: A Pratical Guide to Modelling Cognitive Processes. London: Academic Press.

Mahardi Saputro. 2011. Analisis Kemampuan Pemecahan Masalah Matematika Berdasarkan Langkah Polya ditinjau dari Gaya Kognitif Siswa. Tesis. Surakarta: PPs Universitas Sebelas Maret Surakarta.

National Council of Teacher Mathematics. 2000. Principles and Standards for School Mathematics. Reston, Virginia: National Council of Teachers of Mathematics. (Online). http://www.netm.org/. diakses tanggal 3 Mei 2011.

Patma Supamena. 2009. Proses Berpikir Mahasiswa dalam Mengkonstruksi Bukti Keterbagian. Tesis. Malang: PPs Universitas Negeri Malang.

Patrick Reany. 1991. "Heuristics 101”. Arizona Journal of Natural Philosophy. 3. 57. http://www.ajnpx.com/pdf/AJNP/apr9 1c.pdf. 
Paul Suparno. 2001. Perkembangan Kognitif Jean Piaget. Yogyakarta: Kanisius.

Ratna Wilis Dahar. 1989. Teori Pembelajaran. Bandung: IKIP Bandung.

Rheta DeVries. 2006. Piaget's Social Theory. The Constructivist Journal. 17 (1) ISSN 1091-4072.

Robert L Solso. 1988. Cognitive Psychology. Boston: Allyn and Bacon.

Rudi Kurniawan. 2010. Pemahaman Dan Pemecahan Masalah Matematis (Artikel Kajian Pendidikan Matematika. Makalah disampaikan pada Seminar Nasional Matematika dan Pendidikan Matematika di UNY pada tanggal 27 November 2010.

Sandy D. Melnick. 1974. Piaget and The Pediatrician, Guilding Intellectual Development. Journal of Clinical Pediatrics. 13 (11). 913-918.

Shahnaz Qayumi. 2001. Piaget and His Role in Problem Based Learning. Journal of Investigative Surgery. 14. 63-65.

Sugiyono, 2008. Metode Penelitian Pendidikan Pendekatan Kuantitatif, Kualitatif, dan $R \& D$. Bandung: Alfabeta.

Sukayasa. 2010. Profil Karakteristik Penalaran Siswa SMP dalam Memecahkan Masalah Geometri. Makalah disampaikan pada Seminar Nasional Matematika dan Pendidikan
Matematika di UNY pada tanggal 27 November 2010.

Suparni. 2010. Membangun Karakter Bangsa dengan Teori Polya pada Pembelajaran Matematika. Makalah disampaikan pada Seminar Nasional Matematika dan Pendidikan Matematika di UNY pada tanggal 27 November 2010.

Syaifuddin Azwar. 2007. Metode Penelitian. Yogyakarta: Pustaka Pelajar.

Syaiful Sagala. 2008. Konsep dan Makna Pembelajaran. Bandung: Alfabeta.

Tatag Yuli Eko Siswono. 2007. Penjenjangan Kemampuan Berpikir Kreatif dan Identifikasi Tahap Berpikir Kreatif Siswa dalam Memecahkan dan Mengajukan Masalah Matematika. Disertasi. Surabaya: Universitas Negeri Surabaya.

Wayne A. Wicklelgren. 1974. How to Solve Problem; Elements of a Theory of Problems and Problems Solving. New York: W.H. Freeman and Company.

William Crain. 1992. Theories of Development: Concept and Application. News Jersey: Prentice-Hall.

Wina Sanjaya. 2009. Strategi Pembelajaran Berorientasi Standart Proses Pendidikan. Jakarta: Kencana. 
Yulaelawati. 2004. Kurikulum dan

Pembelajaran: Filosofi Teori dan

Aplikasi, Bandung: Pakar Raya. 